\title{
EDITORIAL
}

\section{Sexually transmitted infections and substance use disorders: evidence and challenges in Mexico}

\author{
Rodrigo Marín-Navarrete, ${ }^{1}$ Carlos Magis-Rodríguez, ${ }^{2}$ Steffanie A. Strathdee ${ }^{3}$
}

\footnotetext{
${ }^{1}$ Unidad de Ensayos Clínicos en Adicciones y Salud Mental, Instituto Nacional de Psiquiatría Ramón de la Fuente Muñiz.

${ }^{2}$ Centro Nacional para la Prevención y Control del VIH y el SIDA (CENSIDA).

${ }^{3}$ Division of Global Public Health, University of California, San Diego, School of Medicine.

Correspondence:

Rodrigo Marín-Navarrete.

Unidad de Ensayos Clínicos en

Adicciones y Salud Mental, Instituto

Nacional de Psiquiatría Ramón de la Fuente Muñiz.

Calz. México-Xochimilco 101

San Lorenzo Huipulco, Tlalpan

14370, Mexico City.

Phone: +52 (55) 4160-5480

E-mail: rmarin@imp.edu.mx

doi.org/10.17711/SM.0185-3325. 2017.001
}

\section{Epidemiology of STI in substance abusers}

According to international reports, Mexico has a high prevalence of sexually transmitted infections (STIs), such as human immunodeficiency virus (HIV), hepatitis B virus (HBV) and hepatitis $\mathrm{C}$ virus (HCV). There are approximately 34 million people infected with HIV (National Center for Prevention and Control of HIV-AIDS [CENSIDA], 2011), between 130 and 150 million with $\mathrm{HCV}$ (WHO, 2014a), approximately 400 million with HBV (Hepatitis B Foundation, 2014), and 12 million infected with syphilis every year (WHO, 2014b).

Great strides have been made in the understanding, treatment and prevention of STIs. For example, the updating of transfusion protocols and standards in 2000 has significantly reduced the incidence of HCV infections by this means (Mathers et al., 2008). On the scientific and public health policy agendas, however, concern remains about specific populations with a greater risk of infection than the general population, such as substance abusers, who are estimated to have a high prevalence of STI (Scheinmann et al., 2007).

Scientific literature reports that HIV prevalence at addiction treatment centers is approximately $3 \%$ among non-injection substance users, as opposed to $27 \%$ among injection substance users (Lehman, Allen, Green \& Onorato, 1994; Prevots et al., 1996). At the same time, a number of studies show that the prevalence of HCV among injection substance users is above $50 \%$ (Aceijas \& Rhodes, 2007), with the largest user populations being found in China, the United States and Russia (Nelson et al., 2011). This information is particularly important in view of the fact that the risk of developing chronic diseases after exposure to HCV is higher among substance abusers than non-users (Page et al, 20093; Piasecki et al., 2004; Poustchi et al., 2011), and over ten times higher among those with substance use disorders (SUD) and other psychiatric disorders (OPD) when compared to the general population (Rosenberg et al. 2001).

Studies in Mexico report that the prevalence of HIV in non-injection substance users oscillates between 3.7\% and 4\% (Deiss et al., 2012; Magis-Rodríguez et al., 2005), while one study on the northern border of Mexico found that $96 \%$ of injection drug users tested positive for HCV antibodies, while $2.8 \%$ were HIV positive. Several studies have also reported that intravenous or intranasal substance users with HIV have an increased risk of HCV co-infection (Alvarado-Esquivel, Sablon, Martínez-García \& Estrada-Martínez, 2005; White et al, 2007).

Another study conducted at outpatient treatment centers for addictions and prisons in the west of Mexico reported a prevalence of $4.1 \%$ of HCV, $5.7 \%$ of HBV and $1.6 \%$ of HIV in the outpatient sample, together with $40 \%$ of HCV, $20 \%$ of HBV and 6.7 of HIV in the prison sample (Campollo et al., 2012).

Despite progress in this field, there are still very few studies in Mexico on STI in substance abusers. However, available data suggest that substance abusers are a high-risk population in comparison with the general population, which has a much lower prevalence ( $0.2 \%$ of HIV and $2 \%$ of HCV) (CENSIDA, 2011; Quer \& Mur, 2014). 


\section{Risky behaviors in substance abusers}

The scientific literature has established a link between substance abuse, risky sexual behavior and STIs. First, substance use can itself constitute risky behavior, since some forms of substance use, such as the use of stimulants like methamphetamines and cocaine increases the likelihood of having sex with multiple partners and not using a condom (Barta et al., 2008; Brown \& Vanable, 2007). Second, it has been estimated that the prevalence of blood-borne infectious diseases is higher among injection substance users than among those who do not inject, since these are easily transmitted by sharing the paraphernalia used to administer drugs. However, some types of infection can also be acquired through the use of contaminated utensils for preparing (cooking) the drug, such as filters, tourniquets and water for rinsing, which may be enough to infect other users (Strathdee et al., 2008). Third, addiction can increase the likelihood of an exchange of substances for sex (Deiss et al., 2012).

\section{Barriers to STI treatment in substance abusers}

Among substance abusers, there are individual factors limiting help-seeking for their detection, diagnosis and treatment. These factors include lack of knowledge about medical comorbidities and their impact on health, misperceptions about STIs and their treatment (Grebely \& Tyndall, 2011; Treloar, Hull, Dore \& Grebely, 2012), absence of symptoms, unemployment, unstable housing, social stigma and barriers to accessing specialized health services (Grebely \& Tyndall, 2011; Treloar, Newland, Rance \& Hopwood, 2010).

Various studies have shown that other significant factors associated with barriers to accessing treatment for STIs include: comorbidity with other medical diseases (Ho et al., 2008), SUD and OPD (Evon et al., 2013; Lieveld et al., 2013).

Common reasons why people with active substance use are inappropriately denied the treatment are: a) serious side effects resulting from the pharmacological interaction of HIV antiretrovirals with opioid agonist treatments like methadone, b) lower response rates due to liver damage caused by alcohol use, and c) concerns about continuous risk of reinfection due to re-exposure to the virus after treatment (Edlin, 2002; Mathurin, Canva, Dharancy \& Paris, 2002; Peters \& Terrault, 2002). These are remediable and should therefore not be contra-indications for treatment.

Other factors include treatment costs (Moirand, Bilodeau, Brissette \& Bruneau, 2007), lack of infrastructure, limited accessibility and long waiting lists for gaining access to evaluation and treatment services (Grebely \& Tyndall, 2011; Swan et al., 2010) as well as the difficulties of ensuring that health professionals adopt screening, assess- ment and treatment procedures (Pai, Vadnais, Denkinger, Engel \& Pai, 2012).

\section{Early detection and initiation of STI treatment in substance abusers}

According to available scientific evidence, early detection of STIs is one of the most important preventive strategies, since it is estimated that a large percentage of infections occur through people who are unaware of their HIV status (Hall, Holtgrave \& Maulsby, 2012). It is also known that people decrease risky sexual behavior once they are told they have positive serostatus (Marks, Crepaz, Senterfitt \& Janssen, 2005). Moreover, there is evidence that people who enter treatment reduce the likelihood of infecting others (Cohen \& Gay, 2010).

These benefits of early detection suggest that performing rapid STI tests is highly recommended because: a) it has been shown that they can assist in detection with a diagnostic efficiency level of over 95\% (Kyle et al., 2015), b) they are cost-effective and easily transportable (Schackman et al., 2013), c) they are highly accepted by patients (Schackman et al., 2013), and d) they contribute to narrowing the gap between infection and late initiation of treatment (Leber et al., 2015).

\section{STIs in people with SUD: a challenge for Mexico}

The situation of STIs in people with SUD poses a challenge for the public health system in Mexico, since, despite efforts made to date to research and address this specific population, there is a gap between the public services for treating STI and those addressing SUD. The corollary of scientific evidence clearly indicates that patients with SUD have a high prevalence of psychiatric comorbidity. This co-occurrence between SUD and OPD also significantly increases risky sexual behavior and risky use behaviors, both of which are directly associated with a high risk of transmission of STIs (Marín-Navarrete et al., 2016).

Moreover, Mexico has limited coverage of public residential services for people with severe SUD. Accordingly, the past 20 years have seen a growing offer of non-profits with more than 2000 self-help based residential centers. (Marín-Navarrete et al, 2016; Pagano, García, Recarte \& Lee 2016). It has also been documented that most of these residential centers lack the physical infrastructure and qualified professionals for proper patient care (Marín-Navarrete et al, 2016; Pagano, García, Recarte \& Lee, 2016), and in extreme cases, violations of patients' human rights have been reported (Lozano-Verduzco, Romero-Mendoza \& Marín-Navarrete, 2016; Lozano-Verduzco, Marín-Navarrete, Romero-Mendoza \& Tena-Suck, 2016). This hampers the implementation of algorithms for early detection of STIs 
and reference and counter-reference procedures designed to reduce the treatment dropout due to the patient's navigation in a complex, divided health system.

\section{REFERENCES}

Aceijas, C. \& Rhodes, T. (2007). Global estimates of prevalence of HCV infection among injecting drug users. International Journal on Drug Policy, 18, 352-358. DOI: http://dx.doi.org/10.1016/j.drugpo.2007.04.004

Alvarado-Esquivel, C., Sablon, E., Martinez-Garcia, S. \& Estrada-Martinez, Z. (2005). Hepatitis virus and HIV infections in inmutes of a state correccional facility in Mexico. Epidemiology \& Infection, 133, 679-685. DOI: https://doi. org/10.1017/S0950268805003961

Anaya, H. D., Hoang, T., Golden, J. F., Goetz, M. B., Gifford, A., Bowman, C., ... Asch, S. M. (2008). Improving HIV screening and receipt of results by nurse-initiated streamlined counseling and rapid testing. Journal of General Internal Medicine, 23(6), 800-7. DOI:10.1007/s11606-008-0617-x

Barta, W.D., Portnoy, D.B., Kiene, S.M., Tennen, H., Abu-Hasaballah, K.S. \& Ferrer, R. (2008). A daily process investigation of alcohol-involved sexual risk behavior among economically disadvantaged problem drinkers living with HIV/ AIDS. AIDS and Behavior, 12, 729-740. DOI: 10.1007/s10461-007-9342-4

Brown, J.L. \& Vanable, P.A. (2007). Alcohol use, partner type, and risky sexual behavior among college students: Findings from an event level study. Addictive Behaviors, 32, 2940-2952. http://dx.doi.org/10.1016/j.addbeh.2007.06.011

Campollo, O., Román, S., Panduro, A., Hernández, G., Díaz-Barriga, L., Balanzario, M.C. \& Cunningham, J.K. (2012). Non-injection drug use and hepatitis C among drug treatment clients in west central Mexico. Drug and Alcohol Dependence, 123, 269-272. http://dx.doi.org/10.1016/j.drugalcdep.2011.11.009

Centro Nacional para la Prevención y Control del VIH-Sida (2006). Guía para la aplicación de la prueba rápida. México: SSA.

Centro Nacional para la Prevención y Control del VIH-Sida (2011). El VIH/SIDA en México 2011. Numeralia epidemiológica. México: SSA.

Cohen, M. S., \& Gay, C. L. (2010). Treatment to prevent transmission of HIV-1. Clinical Infectious Diseases, 50(Supplement 3), S85-S95. DOI: 10.1086/651478

Deiss, R., Lozada, R.M., Burgos, J.L., Strahdee, S.A., Gallardo, M., Cuevas, J., \& Garfein, R.S. (2012). HIV Prevalence and Sexual Risk Behavior among Non-Injection Drug Users in Tijuana, Mexico. Global Public Health, 7, 175-183. DOI: http://dx.doi.org/10.1080/17441692.2010.549141

Edlin, B.R. (2002). Prevention and treatment of hepatitis C in injection drug users. Hepatology, 36, S210-9. DOI: 10.1002/hep.1840360727

Evon, D. M., Esserman, D. A, Bonner, J. E., Rao, T., Fried, M. W., \& Golin, C. E. (2013). Adherence to PEG/ribavirin treatment for chronic hepatitis C: prevalence, patterns, and predictors of missed doses and nonpersistence. Journal of Viral Hepatitis, 20(8), 536-49. DOI: 10.1111/jvh.12079

Grebely, J. \& Tyndall, M.W. (2011). Management of HCV and HIV infections among people who inject drugs. Current Opinion in HIV and AIDS, 6, 501-7. DOI: 10.1097/COH.0b013e32834bcb36

Hall, H. I., Holtgrave, D. R., \& Maulsby, C. (2012). HIV transmission rates from persons living with HIV who are aware and unaware of their infection. Aids, 26(7), 893-896. DOI: 10.1097/QAD.0b013e328351f73f

Hepatitis B Foundation. (2014). Statistics. Available in: http://www.hepb.org/hepb/ statistics.htm

Ho, S.B., Groessl, E., Dollarhide, A., Robinson, S., Kravetz, D., \& Dieperink, E. (2008). Management of chronic hepatitis C in veterans: the potential of integrated care models. The American Journal of Gastroenterology, 103, 1810-23. DOI:10.1111/j.1572-0241.2008.01877.x

Kyle, T. L., Horigian, V. E., Tross, S., Gruber, V. A., Pereyra, M., Mandler, R. N., ... \& Metsch, L. R. (2015). Uptake of HIV testing in substance use disorder treatment programs that offer on-site testing. AIDS and Behavior, 19(3), 536-542. DOI: 10.1007/s10461-014-0864-2

Lai, C., Gane, E., Liaw, Y. Hsu, C., Thongsawsat, S., Wang, Y... Brown, N. A. (2007). Telbivudine versus lamivudine in patients with chronic hepatitis B. New England Journal of Medicine, 357, 2576-2588. DOI: 10.1056/NEJMoa066422
Lalesta, M., Dillon, B., Padilla, S., Brooks, L., Raveneau, L., \& Metcalf, C. (2000). Experience with HIV/STD prevention counseling with a rapid HIV test and counseling quality assurance (Respect-2). 2000 National STD Prevention Conference, Milwaukee, WI.

Leber, W., McMullen, H., Anderson, J., Marlin, N., Santos, A. C., Bremner, S., ... \& Griffiths, C. (2015). Promotion of rapid testing for HIV in primary care (RHIVA2): a cluster-randomised controlled trial. The Lancet HIV, 2(6), e229-e235. DOI: http://dx.doi.org/10.1016/S2352-3018(15)00059-4

Lehman, J.S., Allen, D.M., Green, T.A. \& Onorato, I.M. (1994). HIV infection among non-injecting drug usersentering drug treatment, United States, 1989-1992. Field Services Branch. AIDS, 8, 1465-1469.

Lieveld, F. I., van Vlerken, L. G., Siersema, P. D., \& van Erpecum, K. J. (2013). Patient adherence to antiviral treatment for chronic hepatitis B and C: a systematic review. Annals of Hepatology, 12(3), 380-91.

Lozano-Verduzco, I., Marín-Navarrete, R., Romero-Mendoza, M., \& Tena-Suck, A. (2016). Experiences of Power and Violence in Mexican Men Attending Mutual-Aid Residential Centers for Addiction Treatment. American Journal of Men's Health. 10(3) 237-249. DOI: 10.1177/1557988314565812

Lozano-Verduzco, I., Mendoza-Romero, M. \& Marín-Navarrete, R. (2016). Violence narratives of Mexican women treated in mutual-aid residential centers for addiction treatment. Substance Abuse Treatment, Prevention, and Policy. 11:39, 1-10. DOI: 10.1186/s13011-016-0083-0

Magis-Rodriguez, C., Brouwer, K.C., Morales, S., Gayet, C., Lozada, R., Ortíz-Mondragón, R.,... Strathdee, S.A. (2005). HIV prevalence and correlates of receptive needle sharing among injection drug users in the Mexican-U.S. border city of Tijuana. Journal of Psychoactive Drugs, 37, 333-339. DOI: http://dx.doi.org/10 $.1080 / 02791072.2005 .10400528$

Marín-Navarrete, R., Medina-Mora ME, Horigian VE, Salloum I., Villalobos-Gallegos L. \& Fernandez-Mondragón, J. (2016). Co- Occurring disorders: A challenge for Mexican community based-residential care facilities for substance use. Journal of Dual Diagnosis, 12:3-4, 261-270. DOI: 10.1080/15504263.2016.1220207.

Marks, G., Crepaz, N., Senterfitt, J. W., \& Janssen, R. S. (2005). Meta-analysis of high-risk sexual behavior in persons aware and unaware they are infected with HIV in the United States: implications for HIV prevention programs. JAIDS Journal of Acquired Immune Deficiency Syndromes, 39(4), 446-453. DOI: 10.1097/01.qai.0000151079.33935.79

Mathers, B. M., Degenhardt, L., Phillips, B., Wiessing, L., Hickman, M., Strathdee, S. A., ... \& Mattick, R. P. (2008). Global epidemiology of injecting drug use and HIV among people who inject drugs: a systematic review. The Lancet, 372(9651), 1733-1745. DOI: http://dx.doi.org/10.1016/S0140-6736(08)61311-2

Mathurin, P., Canva, V., Dharancy, S. \& Paris, J.C. (2002). Treatment of chronic hepatitis $\mathrm{C}$ and alcohol consumption. Gastroentérologie Clinique et Biologique, 26, B248-51.

Moirand, R., Bilodeau, M., Brissette, S. \& Bruneau, J. (2007). Determinants of antiviral treatment initiation in a hepatitis $\mathrm{C}$-infected population benefiting from universal health care coverage. Canadian Journal of Gastroenterology \& Hepatolgy, 21, 355-361. DOI: http://dx.doi.org/10.1155/2007/576765

Nelson, P. K., Mathers, B. M., Cowie, B., Hagan, H., Des Jarlais, D., Horyniak, D. \& Degenhardt, L. (2011). Global epidemiology of hepatitis B and hepatitis C in people who inject drugs: Results of systematic reviews. The Lancet, 378, 571-583. DOI: http://dx.doi.org/10.1016/S0140-6736(11)61097-0

Organización Mundial de la Salud (OMS, 2014a). Hepatitis C. Disponible en: http:// www.who.int/mediacentre/factsheets/fs164/es/

Organización Mundial de la Salud (OMS, 2014b). Eliminación Mundial de la Sífilis Congénita: fundamentos y estrategia para la acción. Disponible en: http://www. who.int/reproductivehealth/publications/rtis/9789241595858/es/

Pagano A, García V, Recarte C, Lee JP. Sociopolitical contexts for addiction recovery: Anexos in U.S. Latino communities. International Journal of Drug Policy. 2016; 37:52-9. DOI: 10.1016/j.drugpo.2016.08.002.

Page, K., Hahn, J. A., Evans, J., Shiboski, S., Lum, P., Delwart, E., . . B Busch, M. P. (2009). Acute hepatitis $C$ virus infection in young adult injection drug users: A prospective study of incident infection, resolution, and reinfection. Journal of Infectious Diseases, 200, 1216-1226. DOI: 10.1086/605947

Pai, N.P., Vadnais, C., Denkinger, C., Engel, N. \& Pai, M. (2012). Point-of-Care Testing for Infectious Diseases: Diversity, Complexity, and Barriers in Low- 
And Middle-Income Countries. PLoS Medicine, 9, 1-7. DOI: http://dx.doi. org/10.1371/journal.pmed.1001306

Peters, M.G. \& Terrault, N.A. (2002). Alcohol use and hepatitis C. Hepatology, 36, S220-5. DOI: 10.1053/jhep.2002.36811

Piasecki, B. A., Lewis, J. D., Reddy, K. R., Bellamy, S. L., Porter, S. B., Weinrieb, R. M., ... Chang, K. M. (2004). Influence of alcohol use, race, and viral coinfections on spontaneous HCV clearance in a US veteran population. Hepatology, 40, 892-899. DOI: 10.1002/hep.1840400419

Poustchi, H., Esmaili, S., Mohamadkhani, A., Nikmahzar, A., Pourshams, A., Sepanlou, S. G., . . Malekzadeh, R. (2011). The impact of illicit drug use on spontaneous hepatitis $\mathrm{C}$ clearance: Experience from a large cohort population study. PLoS ONE, 6(8), e23830. DOI: http://dx.doi.org/10.1371/journal.pone.0023830

Prevots, D.R., Allen, D.M., Lehman, J.S., Green, T.A., Petersen, L.R. \& Gwinn, M. (1996). Trends in human immunodeficiency virus seroprevalence among injection drug users entering drug treatment centers, United States, 19881993. American Journal of Epidemiology, 143, 733-742. DOI: https://doi. org/10.1093/oxfordjournals.aje.a008807

Quer, J. y Estaban-Mur, J. I. (2014). Hepatitis C virus: Epidemiology and prevention. in Thomas, H. C., Lok, A. S. F., Locarnini, S. A., \& Zuckerman, A. J. (Eds.). Viral Hepatitis (246-265). UK: Wiley Blackwell

Rosenberg, S. D., Goodman, L. a, Osher, F. C., Swartz, M. S., Essock, S. M., Butterfield, M. I., ... Salyers, M. P. (2001). Prevalence of HIV, hepatitis B, and hepatitis $\mathrm{C}$ in people with severe mental illness. American Journal of Public Health, 91(1), 31-7.

Schackman, B. R., Metsch, L. R., Colfax, G. N., Leff, J. A., Wong, A., Scott, C. A., ... \& Walensky, R. P. (2013). The cost-effectiveness of rapid HIV testing in substance abuse treatment: results of a randomized trial. Drug and alcohol dependence, 128(1), 90-97. DOI: http://dx.doi.org/10.1016/j.drugalcdep.2012.08.009

Scheinmann, R., Hagan, H., Lelutiu-Weinberger, C., Stern, R., Des Jarlais, D. C., Flom, P. L., \& Strauss, S. (2007). Non-injection drug use and hepatitis C virus: a systematic review. Drug and alcohol dependence, 89(1), 1-12. DOI: http:// dx.doi.org/10.1016/j.drugalcdep.2006.11.014

Strathdee, S.A., Philbin, M.M., Semple, S.J., Pu, M., Orozovich, P., Martínez, G.,... Patterson, T.L. (2008). Correlates of injection drug use among female sex workers in two Mexico-U.S. border cities. Drug and Alcohol Dependence, 92, 13240. DOI: http://dx.doi.org/10.1016/j.drugalcdep.2007.07.001

Swan, D., Long, J., Carr, O., Flanagan, J., Irish, H., Keating, S.,... Cullen, W. (2010). Barriers to and facilitators of hepatitis $\mathrm{C}$ testing, management, and treatment among current and former injecting drug users: a qualitative exploration. AIDS Patient Care and STDS, 24, 753-62. DOI:10.1089/apc.2010.0142.

The PLoS Medicine Editors (2011). Speed and Convenience Aren't Everything with Diagnostics. PLoS Medicine, 8, e1001113. DOI: http://dx.doi.org/10.1371/journal.pmed.1001113

Treloar, C., Hull, P., Dore, G.J. \& Grebely, J. (2012). Knowledge and barriers associated with assessment and treatment for hepatitis $\mathrm{C}$ virus infection among people who inject drugs. Drug and Alcohol Review, 31, 918-24. DOI: 10.1111/j.14653362.2012.00468.x

Treloar, C., Newland, J., Rance, J. \& Hopwood, M. (2010). Uptake and delivery of hepatitis $\mathrm{C}$ treatment in opiate substitution treatment: perceptions of clients and health professionals. Journal of Viral Hepatitis, 17, 839-44. DOI: 10.1111/j.1365-2893.2009.01250.x

Viani, R. M., Araneta, M. R. G., Ruiz-Calderon, J., Hubbard, P., Lopez, G., ChacónCruz, E., \& Spector, S. A. (2006). Perinatal HIV counseling and rapid testing in Tijuana, Baja California, Mexico: seroprevalence and correlates of HIV infection. JAIDS Journal of Acquired Immune Deficiency Syndromes, 41(1), 87-92.

White, E.F., Garfein, R.S., Brouwer, K.C., Lozada, R., Ramos, R., Firestone, M., et al. (2007). Prevalence of hepatitis $C$ virus and HIV among injection drug users in two mexican cities bordering the US. Salud Pública Mexico, 49, 165-172. DOI: http://dx.doi.org/10.1590/S0036-36342007000300001 